\title{
PENGARUH DANA DESA TERHADAP TINGKAT KEMISKINAN DAN KESEJAHTERAAN MASYARAKAT DI KABUPATEN/KOTA PROVINSI BALI
}

\author{
Made Krisna Kalpika Sunu ${ }^{1}$ \\ Made Suyana Utama ${ }^{2}$ \\ ${ }^{12}$ Fakultas Ekonomi dan Bisnis Universitas Udayana (Unud), Bali, Indonesia \\ E-mail:krisnakalpikasunu@gmail.com
}

\begin{abstract}
The purpose of this study was to analyze the effect of village funds on the level of poverty and the welfare of the community in the regency / city of the Province of Bali. Village fund data was obtained from the Bali Province Community and Village Empowerment Service, while the poverty rate and Human Development Index were obtained from the Central Statistics Agency of Bali Province in 2015-2017. The data analysis technique used in this study is descriptive statistics and path analysis. The results of this study indicate that village funds have a negative and significant effect on poverty levels. This means that the higher the village fund, the lower the poverty rate. Village funds have a positive and significant effect on people's welfare. This means that the higher the village funds, the higher the welfare of the community in the area. The poverty level has a negative and significant effect on people's welfare, meaning that the higher the poverty level, the lower the welfare of the community.
\end{abstract}

Keywords: village fund; poverty level. community welfare.

\begin{abstract}
ABSTRAK
Tujuan dari penelitian ini untuk menganalisis pengaruh dana desa terhadap tingkat kemiskinan dan kesejahteraan masyarakat di kabupaten/kota Provinsi Bali.Data dana desa diperoleh dari Dinas Pemberdayaan Masyarakat dan Desa Provinsi Bali, sedangkan tingkat kemiskinan dan Indeks Pembangunan Manusia diperoleh dari Badan Pusat Statistik Provinsi Bali pada tahun 2015-2017. Teknik analisis data yang digunakan pada penelitian ini yaitu statistik deskriptif dan path analysis. Hasil penelitian ini menunjukkan bahwa Dana desa berpengaruh negatif dan signifikan terhadap tingkat kemiskinan. Artinya bahwa semakin tinggi dana desa maka semakin turun tingkat kemiskinan. Dana desa berpengaruh positif dan signifikan terhadap kesejahteraan masyarakat. Artinya bahwa semakin tinggi dana desa maka akan semakin tinggi kesejahteraan masyarakat di daerah tersebut. Tingkat kemiskinan berpengaruh negatif dan signifikan terhadap kesejahteraan masyarakat artinya semakin tinggi tingkat kemiskinan maka semakin menurun kesejahteraan masyarakat.
\end{abstract}

Kata Kunci: dana desa; tingkat kemiskinan; kesejahteraan masyarakat.

\section{PENDAHULUAN}

Kesejahteraan merupakan hal yang ingin dicapai semua orang, walaupun untuk mencapainya seseorang harus bekerja keras. Kesejahteraan memiliki banyak dimensi, yakni dapat dilihat dari dimensi materi dan dimensi non materi. Dari sisi materi dapat diukur dengan pendekatan pendapatan dan konsumsi 
(Hukom,2014). Pemerintah baik pusat maupun daerah pasti memiliki tujuan untuk mensejahterakan masyarakatnya seperti yang tertera dalam UUD 1945. Salah satu cara yang dilakukan pemerintah yaitu melalui pembangunan (Putra dan Sri Budhi, 2015).Kesejahteraan masyarakat merupakan tujuan dan upaya yang dilakukan pemerintah melalui upaya-upaya seperti peningkatan pertumbuhan ekonomi (Edogbanya et al, 2013).Pertumbuhanekonomi memang penting, strategi penanggulangan kemiskinan yang lebih lengkap harus mengambilfaktor yang relevan, dalam konteks desentralisasi, analisis subnasionaldapat menjadi pendekatan instruktif untuk memeriksa pemerintahan lokal dalam kaitannya denganpertumbuhan dan pengentasan kemiskinan (Balisacan,2003). Mengeksplorasi tantangan pertumbuhan ekonomi yang dihadapi oleh ekonomi yang melimpahdalam tenaga kerja dan sumber daya alam dalam ekonomi global yang semakin maju,bahwa penghargaan spesialisasi yang semakin didominasi oleh beberapa negara berkembang yang sangat besar, terutama Cina (Coxhead,2008). Keberhasilan pembangunan yang dilaksanakan oleh sebuah negara termasuk Negara Indonesia dapat dilihat dari kondisi kesejahteraan masyarakatnya (Marhaeni, 2014).Dalam proses pembangunan selalu diupayakan pertumbuhan ekonomi adalah setinggi mungkin (Dayuh, 2012).Pertumbuhan ekonomi menerangkan atau mengukur prestasi dari perkembangan sesuatu ekonomi. (Odhiambo,2009). Nurudeen (2010) menyatakan bahwa, pemerintah memiliki peran yang besar dalam pembangunan. Peran pemerintah dalam meningkatkan pertumbuhan ekonomi sangat besar melalui pembiayaan yang dilakukan oleh pemerintah (Dalamagas, 2010).Pembangunan itu sendiri memiliki 
tujuan utama yaitu kesejahteraan masyarakat. Kesejahteraan masyarakat yang dimaksud dapat dilihat dari pertumbuhan ekonomi dan distribusi pendapatannya (Artana Yasa dan Arka, 2015). Menurut Kaur (2016), pertumbuhan ekonomi juga dipengaruhi oleh teknologi dan pengetahuan.Pertumbuhan ekonomi, akan menciptakan investasi, membuka lapangan kerja, menyerap angkatan kerja, yang pada gilirannya akan mengurangi kemiskinan penduduk (Sirilius Seran, 2017).

Pembangunan itu bersifat dinamis dan multidimensional, pembangunan dilakukan untuk mencapai sasaran utama yaitu kesejahteraan masyarakat di suatu Negara atau daerah. Menurut Indradewi dan Marhaeni (2016) salah satu cara meningkatkan pendapatan masyarakat agar dapat merasakan kehidupan yang layak adalah melalui pembangunan ekonomi yang merata di setiap wilayah. Pembangunan dapat berupa sarana dan prasarana infrastruktur yang mendukung semua sektor yang ada dan pengentasan masalah kemiskinan guna meningkatkan pendapatan penduduk miskin. Persoalan utama yang dapat menghambat pembangunan salah satunya yaitu kemiskinan. Masalah kemiskinan merupakan masalah yang sangat kompleks yang bersifat negatif dan berdampak buruk bagi kemajuan suatu daerah, jadi masalah kemiskinan ini harus dapat diberantas sampai ke akar-akarnya (Wirawan, 2015). Masih adanya penduduk miskin di beberapa wilayah artinya strategi pemerintah untuk menaikkan taraf hidup masyarakatnya belum benar-benar efektif dilaksanakan.

Pada umumnya di dalam rumah tangga miskin penghasilan per hari sangat diprioritaskan karena konsumsinya hari ini sangat bergantung pada penghasilannya hari ini juga. Rumah tangga miskin dalam mempertahankan 
kehidupannya selalu memikirkan sisi pengeluaran dan sisi pendapatannya, dimana rumah tangga miskin selaiu berupaya meminimalkan pengeluarannya dan memaksimalkan pendapatannya. Upaya itu dilakukan semata - mata untuk memenuhi kebutuhan sehari hari dan bisa mendapatkan kehidupan yang layak. Kehidupan yang layak bagi rumah tangga miskin sangat sulit dicapai hanya dengan upaya - upaya seperti itu. Pendapatan yang sedikit yang hanya dapat digunakan untuk memenuhi kehidupan sehari hari, membuat orang - orang yang berada dibawah kemiskinan harus bekerja keras setiap harinya. Peran pemerintah dalam hal ini sangat dibutuhkan untuk membantu rumah tangga miskin agar dapat hidup dengan layak (Haryanto, 2008).

Kemiskinan memang merupakan masalah yang kompleks yang dapat menyerang daerah manapun, tidak terkecuali pulau Bali. Bali daerah yang dikenal dengan sebutan pulau seribu pura atau pulau dewata yang menjadi daerah tujuan wisata dunia, banyak yang mengira masyarakat di Bali pasti jauh dari kata kemiskinan. Kenyataannya Bali juga tidak lepas dari masalah kemiskinan.

Tabel 1.

Indeks Pembangunan Manusia Menurut Kabupaten/Kota di Provinsi Bali Tahun 2015-2017

\begin{tabular}{lccc}
\hline \multirow{2}{*}{ Kabupaten/Kota } & \multicolumn{3}{c}{ Indeks Pembangunan Manusia (\%) } \\
& $\mathbf{2 0 1 5}$ & $\mathbf{2 0 1 6}$ & $\mathbf{2 0 1 7}$ \\
\hline Jembrana & 69.66 & 70.38 & 70.72 \\
Tabanan & 73.54 & 74.19 & 74.86 \\
Badung & 78.86 & 79.80 & 80.54 \\
Gianyar & 75.03 & 75.70 & 76.09 \\
Klungkung & 68.98 & 69.31 & 70.13 \\
Bangli & 66.24 & 67.03 & 68.24 \\
Karangasem & 64.68 & 65.23 & 65.57 \\
Buleleng & 70.03 & 70.65 & 71.11 \\
Denpasar & 82.24 & 82.58 & 83.01 \\
Provinsi Bali & 73.27 & 73.65 & 74.30 \\
\hline Sumber: Badan & &
\end{tabular}


Dilihat dari Tabel 1 presentase indeks pembangunan manusia mengalami peningkatan. Pada tahun 2017 presentase indeks pembangunan manusia di Bali menempati tempat tertinggi yaitu 74.30 persen, dimana pada tahun 2015 presentase indeks pembangunan manusia di Provinsi Bali terendah sebesar 73.27 persen. Bali telah terkenal sebagai tujuan wisata sejak tahun 1920-an (Picard, 2003).Bali merupakan rumah bagi sebagian besar minoritas Hindu di Indonesia yang memiliki pantai yang indah, keanekaragaman hayati serta warisan seni dan budaya sehingga menciptakan peluang dalam sektor pariwisata (Tajeddini et al, 2017). Menurut Viken (2011) pariwisata adalah segala kegiatan wisata danwisatawan. Gjorgievski et. al. (2013) mengemukakan peranan sektor pariwisata dalam perekonomian dapat dilihat dari pengeluaran wisatawan terhadap barang dan jasa di daerah tujuan wisata. Kontribusi sektor pariwisata berdampak besar terhadap pendapatan daerah (Vojnovic dan Knezevic, 2013). Kenyataannya daerah yang sering menjadi tujuan wisata turis-turis asing ataupun domestik, cenderung memiliki pendapatan yang tinggi ternyata tidak menutup kemungkinan masih terdapat masalah kemiskinan.

Kualitas sumber daya manusia dapat menjadi faktor penyebab utama terjadinya kemiskinan. Kualitas sumber daya manusia dapat dilihat dari Indeks Pembangunan Manusia (IPM). Menurut Mudrajad (2006) IPM bermanfaat untuk membandingkan kinerja pembangunan manusia baik antar negara maupun antardaerah. Indeks Pembangunan Manusia (IPM) merupakan indikator yang menjelaskan bagaimana penduduk suatu wilayah mempunyai kesempatan untuk mengakses hasil dari suatu pembangunan sebagai bagian dari haknya dalam 
memperoleh pendapatan, kesehatan, pendidikan, dan sebagainya. Dengan masyarakat yang sehat dan berpendidikan yang baik, peningkatan produktifitas masyarakat akan meningkatkan pula pengeluaran untuk konsumsinya, ketika pengeluaran untuk konsumsi meningkat, maka tingkat kemiskinan akan menurun. Disisi lain, rendahnya Indeks Pembangunan Manusia (IPM) berakibat pada rendahnya produktivitas kerja dari penduduk. Rendahnya produktivitas berakibat pada rendahnya perolehan pendapatan. Sehingga dengan rendahnya pendapatan menyebabkan tingginya jumlah penduduk miskin (Sukmaraga, 2011: 8).

Upaya pemerintah dalam meningkatan kesejahteraan masyaraka bisa dikelompokkan menjadi dua yaitu pertama, ditujukkan untuk orang-orang yang miskin seperti: bantuan beras untuk orang miskin, bantuan langsung tunai, jaminan kesehatan jaminan kesehatan dan PNPM mandiri. Kedua, ditujukan kepada seluruh masyarakat misalnya, pengurangan biaya sekolah (BOS) danpendanaan pelayanan kesehatan (Sutikno dkk, 2010). Ada tiga strategi utama yang harus dilakukan dalam menanggulangi masalah kemiskinan yaitu bantuan sosial seperti memberikan akses bagi rumah tangga miskin untuk mendapatkan pelayanan baik itu pendidikan, kesehatan, air bersih dan kebutuhan gizi, melakukan pemberdayaan kepada masyarakat miskin agar mampu meningkatkan taraf hidupnya menjadi lebih baik lagi dan yang terakhir adalah memberikan bantuan berupa kredit bagi usaha ekonomi mikro dan kecil (Putra dan Sri Budhi, 2015).

Banyaknya strategi yang sudah dilakukan pemerintah untuk mengatasi masalah kemiskinan namun strategi itu belum mampu menekan angka kemiskinan 
(Dariwardani, 2014). Peran pemerintah daerah maupun pusat memang sangat diperlukan dalam meningkatkan kesejahteraan masyarakat di daerah. Sejak tahun 2015, pemerintah memberikan Dana Desa kepada desa yang bersumber dari APBN yang ditransfer melalui APBD kabupaten/ kota. Desa mempunyai hak untuk mengelola kewenangan dan pendanaannya.

Kenyataannya dengan adanya dana bantuan keuangan khusus kepada desa tidak diikuti dengan peningkatan kesejahteraan masyarakat yang merata di kabupaten/kota di Provinsi Bali dilihat dari Tabel 1 pada kabupaten Jembrana, Bangli, Karangasem dan Buleleng masih dibawah rata-rata kesejahteraan masyarakat Provinsi Bali, padahal seharusnya pemberian bantuan khusus keuangan dapat menunjang pertumbuhan perekonomian masyarakat dan diharapkan mampu mengatasi permasalahan-permasalahan yang dialami masyarakat selama ini (Wirawan, 2015).

Salah satu tujuan Alokasi Dana Desa (ADD) adalah sebagai pengentasan kemiskinan dan kesenjangan serta meningkatkan kesejahteraan masyarakat. Dalam penggunaannya, 30 persen ADD digunakan untuk biaya operasional penyelenggaraan pemerintah desa dan 70 persen digunakan untuk pembangunan fisik dan pemberdayaan masyarakat (Nurcholis, 2011:90).Sebagai bagian dari NKRI (Negara Kesatuan Republik Indonesia) pemerintah desa perlu mendapat supervisi dari level pemerintah di atasnya. Hal ini dikarenakan untuk kedepannya, jumlah Dana Desa yang akan diberikan ke desa akan semakin besar sementara kapasitas dan kapabilitas SDM (Sumber Daya Manusia) dalam pengelolaan keuangan desa masih belum cukup memadai. Selain itu, keterlibatan masyarakat 
untuk merencanakan dan mengawasi penggunaan dana desa masih dirasakan minimal. Dengan demikian, ini menjadi tugas dan catatan penting tidak hanya bagi pemerintah pusat, tetapi juga bagi pemerintah kabupaten/kota dan pemerintah desa serta masyarakat untuk membangun desa secara kolektif (Azis, 2016).

Berkenaan dengan dikucurkannya dana desa dan alokasi dana desa diharapkan proses pembangunan daerah secara keseluruhan akan dapat ditingkatkan dan secara bersama ketimpangan pembangunan antar wilayah akan pula dapat dikurangi. Alokasi dana yang merata dan tepat sasaran serta pengelolaan sumber-sumber pendapatan secara optimal, efisien dan efektifitas dalam penggunaan anggaran belanja merupakan hal pokok yang harus selalu diperioritaskan. Pemerintah memiliki posisi yang sangat penting dalam menciptakan keadilan distribusi, karena menciptakan kesejahteraan di masyarakat merupakan kewajiban seluruh agen ekonomi.Disamping itu, pemerintah juga berperan sebagai penjamin terciptanya distribusi yang adil serta menjadi fasilitator pembangunan manusia dan menciptakan kesejahteraan masyarakat (Pitri, 2018).

Dana desa merupakan dana yang bersumber dari APBN yang diperuntukkan untuk desa, dananya ditransfer melalui anggaran belanja daerah kabupaten. Dana Desa ini digunakan untuk membiayai penyelenggaraan pemerintahan desa, pelaksanaan pembangunan desa, pembinaan kemasyarakatan desa, dan pemberdayaan masyarakat desa. Tujuan dana desa adalah untuk mengentaskan kemiskinan. Hal ini didukung oleh penelitian Dewi dan Irama (2018) menyatakan bahwa dana desa berpengaruh secara signifikan terhadap kemiskinan. 
Pemberian dana desa merupakan wujud dari pemenuhan hak desa untuk menyelenggarakan otonominya agar tumbuh dan berkembang. Peran pemerintah desa dalam memberikan pelayanan, kesejahteraan masyarakat dan mempercepat pembangunan serta pertumbuhan wilayah-wilayah strategis harus ditingkatkan, sehingga dapat mengembangkan wilayah-wilayah yang masih tertinggal dalam suatu sistem wilayah pengembangan. Penelitian ini didukung oleh penelitian Dura (2016) yang menyatakan bahwa dana desa berpengaruh secara signifikan terhadap kesejahteraan masyarakat.

Menurut (Ginting, 2008) menyatakan pembangunan manusia di Indonesia adalah identik dengan pengurangan kemiskinan. Investasi dibidang pendidikan dan kesehatan akan lebih berarti bagi penduduk miskin dibandingkan penduduk tidak miskin, karena aset utama penduduk miskin adalah tenaga kasar mereka. Tersedianya fasilitas pendidikan dan kesehatan murah akan sangat membantu untuk meningkatkan produktivitas masyarakat, dan pada gilirannya meningkatkan pendapatan masyarakat tersebut. Dengan demikian dapat dikatakan bahwa pembangunan manusia belum secara optimal dilakukan karena hanya terfokus pada pengurangan kemiskinan.

Menurut Bappenas (dalam khuzaironi, 2015) kemiskinan adalah suatu kondisi dimana seseorang atau sekelompok orang tidak mampu untuk memenuhi kehutuhannya. Menurut Mubyarto (dalam Putra dan Sri Budhi, 2015) kemiskinan adalah kondisi serba kekurangan yang disebabkan oleh terhatasnya kepemilikan modal, pengetahuan dan ketrampilan yang rendah, produktivitas yang rendah, 
pendapatan rendah, dan terbatasnya kesempatan berperan serta dalam pembangunan.

Pada tingkat nasional maupun regional, kemiskinan telah menjadi masalah yang kompleks dan kronis, sehingga diperlukan strategi yang tepat dan berkelanjutan untuk menanggulanginya (Margareni dkk, 2016).Kemiskinan bukanlah suatu keadaan dimana terjadi kekurangan pendapatan untuk membeli sekeranjang barang melainkan kemiskinan merupakan keadaan kekurangan sumber daya. Pendapat yang sama juga dipaparkan oleh Rothwell dan Jennifer (2008) yaitu kemiskinan itu merupakan kekurangan sumber daya yang memadai. Di Eropa istilah kemiskinan lebih menggambarkan tentang kerugian ekonomi yang dihadapi individu (Gustafsson et al., 2007).

Menurut Adam Smith (Pramitha dkk., 2015) kemiskinan tidak hanya sebatas kesulitan untuk memenuhi kebutuhan pokok semata melainkan juga karena ketidakmampuan dalam menegakkan HAM dan ketidakmampuan dalam memperoleh pendidikan. Sama halnya dengan Adam Smith, Shaughnessy (2014) menyatakan bahwa anak- anak dari masyarakat miskin memiliki masalah padaperkembangannya, kesehatan mental dan memiliki pendidikan yang lebih rendah dari anak-anak lainnya. Berdasarkan UNDP dalam Iaporan Human Development Report 1997 ukuran kerniskinan disehut dengan Indeks Kemiskinan Manusia (Human Poverty Index-HPI). Kemiskinan dapat diukur dengan tiga hal utama yaitu kehidupan, pendidikan dasar, serta keseluruhan ketetapan ekonomi. Salah satu teori kemiskinan yaitu teori demokrasi sosial, dimana kemiskinan bukanlah masalah individu melainkan masalah struktural. 
Yuki Sekine (2008) memiliki pendapat bahwa kemiskinan tidak hanya masalah pendapatan tetapi juga mengenai kekurangan kapasitas pelayanan sosial dan kebebasan individu dalam mewujudkan dirinya menjadi lebih baik. Chamber (Rudy Syaf, 2013) mengatakan ada dua macam situasi kemiskinan yaitu penyebab kemiskinan karena berada pada daerah yang terpencil dan tidak memiliki sumber daya yang memadai untuk memenuhi kebutuhannya dan kemiskinan yang terjadi karena adanya ketimpangan yang mencolok antara masyarakat kaya dan masyarakat miskin di suatu daerah yang sama. Menurut Yusuf dan Sumner (2015) faktor utama yang meningkatkan kemiskinan seperti halnya di Indonesia adalah adanya kenaikan harga bahan bakar dan kenaikan harga bahan makanan pokok seperti beras. Dua hal itulah yang dianggap meningkatkan kemiskinan karena dengan meningkatnya harga bahan bakar dan bahan makanan pokok masyarakat menjadi tidak mampu untuk membelinya.

Kriteria pengukuran kemiskinan menurut Badan Pusat Statistik yaitu, Luas lantai rurnah kurang dari $8 \mathrm{~m}^{2}$, lantai rumah terbuat dari tanah/bambu/kayu, dinding rumah terhuat dari bambu/tembok tanpa diplester/kayu berkualitas rendah, tidak mempunyai kamar mandi/tempat buang air besar, tidak menggunakan listrik, air yang diminum berasal dari sumur/sungai/mata air/air hujan, bahan bakar yang digunakan untuk memasak yaitu kayu bakar/arang/minyak tanah, hanya mengkonsumsi daging/susu/ayam satu minggu sekali, hanya membeli satu stel pakaian dalam satu tahun, makan hanya satu atau dua kali sehari, tidak sanggup membayar pengobatan di puskesmas, penghasilan di bawah Rp 600.000 per bulan dengan mata pencarian petani dengan lahan 0,5 
ha, buruh bangunan, nelayan, pendidikan kepala keluarga tidak sekolah/tidak tamat $\mathrm{SD} /$ hanya tamat $\mathrm{SD}$, tidak memiliki sepeda motor, tabungan dan emas.

Menurut Suhartini dan Yuta (2014) masalah utama dalam pernbangunan adalah pengentasan kemiskinan. Kebijakan atau upaya-upaya untuk meningkatkan kesejahteraan masyarakat miskin sangatlah penting (Mendes, 2009). Kepedulian pemerintah sangat memberi dampak bagi peningkatan kemiskinan (Ashcroft dan David, 2008). Jadi menurut Ceu Thang dan Baharuddin (2011) pemerintah memiliki tanggung jawab untuk memberantas kemiskinan. Upaya-upaya pengentasan kemiskinan yang dilakukan pemerintah di Indonesia yang bersifat langsung dalam bentuk program-program seperti bantuan raskin, bantuan langsung tunai (BLT), dana BOS, Jamkesmas, Program perlindungan sosiai, bedah rumah, usaha ekonorni Produktif (UEP). Di Malaysia untuk meningkatkan kualitas hidup masyarakatnya terutama masyrakat miskin yaitu dengan menyediakan rumah yang memadai dan berkualitas yang harganya dapat dijangkau semua tingkat pendapatan (Bakhtyar et al., 2013).

Masih berkaitan dengan pengukuran kemiskinan melalui pendekatan pengeluaran, BPS menggunakan konsep kemampuan memenuhi kebutuhan dasar (Basic needs approach) untuk mengukur kemiskinan. Dengan pendekatan ini, kemiskinan dipandang sebagai ketidakmampuan dari sisi ekonomi untuk memenuhi kebutuhan dasar makanan dan bukan makanan yang diukur dari sisi pengeluaran. Metode yang digunakan adalah menghitung Garis Kemiskinan (GK), yang terdiri dari dua komponen yaitu Garis Kemiskinan Makanan (GKM) dan Garis Kemiskinan Non Makanan (GKNM). Penduduk miskin adalah penduduk 
yang memiliki rata-rata pengeluaran per kapita perbulan dibawah Garis kemiskinan. GKM merupakan nilai pengeluaran kebutuhan minimum makanan yang disertakan dengan 2.100 kilokalori perkapita perhari. Paket komoditi kebutuhan dasar makanan diwakili oleh 52 jenis komoditi (padi-padian, umbiumbian, ikan, daging, telur dan susu, sayur-sayuran, kacang-kacangan, buahbuahan, minyak dan lemak, dll). Sedangkan GKNM adalah kebutuhan minimum untuk perumahan, sandang, pendidikan dan kesehatan. Paket komoditi kebutuhan dasar non makanan diwakili oleh 51 jenis komoditi perkotaan dan 47 jenis komoditi di perdesaan. Nilai kebutuhan minimum per komoditi/sub-kelompok non makanan dihitung dengan menggunakan suatu rasio pengeluaran komoditi/sub kelompok tersebut terhadap total pengeluaran komoditi/sub kelompok yang tercatat dalam data Survei Sosial Ekonomi Nasional (SUSENAS) modul konsumsi.

Konsep pembangunan manusia yang direkomendasikan oleh United Nation Development Program (UNDP) mencakup 4 komponen yaitu : pertama, kesetaraan (equality) dalam memperoleh akses sumber daya ekonomi dan politik yang menjadi hak dasar negara dengan syarat distribusi aset-aset ekonomi produktif secara adil, menata sistem kredit perbankan untuk memberikan kesempatan bagi kelompok kecil dan menengah dalam mengembangkan usahanya, menata sistem politik demokratis guna menjamin hak dan kebebasan politik dan menata sistem hukum guna menjamin tegaknya keadilan. Kedua produktivitas (productivity) yang merujuk pada usaha-usaha sistematis yang bertujuan meningkatkan kegiatan ekonomi dengan syarat investasi di bidang 
sumber daya manusia, infrastruktur, dan finansial guna mendukung pertumbuham ekonomi yang pada akhimya kesejahteraan masyarakat akan tercapai. Ketiga, pemberdayaan (empowerment) merupakan setiap upaya untuk membangun kapasitas masyarakat dengan cara melakukan perubahan potensi dan kemampuan, sehingga masyarakat memiliki kemandirian, otonomi, dan otoritas dalam melaksanakan pekerjaan dan mengatasi permasalahan social. Dalam hal ini, pembangunan menempatkan manusia sebagai pusat perhatian yang bertujuan untuk meningkatkan pertumbuhan ekonomi, pendapatan, dan memperluas pilihanpilihan sehingga mantusia memiliki peluang meagembangkan segenap potensi yang dimilikinya. Keempat, berkelanjutan (sustainability) yang berarti bahwa dalam mengelola modal pembangunan fisik manusia, finansial, dan lingkungan agar bisa dimanfaatkan guna meneapai tujuan utama pembangunan yaitu kesejahteraan masyarakat.

United Nation Development Program (UNDP) mendefinisikan pembangunan manusia sebagai suatu "proses untuk memperluas pilihan-pilihan bagi penduduk" (Human Development Report, 2008), dalam arti bahwa manusia diberi pilihan yang lebih banyak dalam memenuhi kebutuhan hidupnya baik yang menyangkut ekonomi, sosial, dan budaya. Ada tiga hal yang dianggap penting untuk pilihan manusia, yaitu untuk memiliki kehidupan yang panjang dan sehat, untuk memperoleh ilmu pengetahuan dan memiliki akses terhadap sumberdaya yang diperlukan untuk mendapat standar hidup yang layak. Apabila tiga faktor yang kritis tersebut tidak dipenuhi maka banyak pilihan lainnya yang tidak akan dapat dicapai, misalnya kemerdekaan politik, ekonomi, sosial, serta kesempatan 
untuk memperoleh tingkat produktivitas yang tinggi, menikmati rasa terhormat dan hak-hak azasi manusia. Konsep pembangunan manusia dalam pengertian di atas jauh lebih luas dari pada teori pembangunan ekonomi yang konvensional, termasuk model pertumbuhan ekonomi, pembangunan sumber daya manusia (SDM), pendekatan kesejahteraan, dan pendekatan kebutuhan kebutuhan dasar manusia.

Model pertumbuhan ekonomi berkaitan dengan peningkatan pendapatan dan produksi nasional (GNP). Pembangunan SDM menempatkan manusia terutama sebagai input dari proses produksi (sebagai suatu sarana bukan tujuan). Pendekatan kesejahteraan melihat manusia sebagai pemanfaat (beneficiaries) bukan sebagai objek perubahan. Pendekatan kebutuhan-kebutuhan dasar memfokuskan pada penyediaan barang dan jasa kebutuhan hidup.

\section{METODE PENELITIAN}

Lokasi penelitian ini dilakukan di kabupaten/kota Provinsi Bali, karena di kabupaten/kota Provinsi Bali masih memiliki tingktat kesejahteraan yang belum merata seperti kabupaten Jembrana, Bangli, Karangasem dan Buleleng masih dibawah rata-rata kesejahteraan masyarakat Provinsi Bali.

Metode pengumpulan data yang digunakan dalam penelitian ini adalah metode observasi nonpartisipan. Teknik analisis data yang digunakan untuk memecahkan permasalahan dalam penelitian ini adalah teknik analisis kuantitatif dengan bantuan program EViews. Penelitian ini diajukan sebagai penelitian empiris untuk mengetahui pengaruh dana desa terhadap indeks pembangunan 
mansuia dan tingkat kemiskinan pada kabupaten/kota di Provinsi Bali. Teknik analisis data yang digunakan adalah teknik analisis jalur (path analysis).

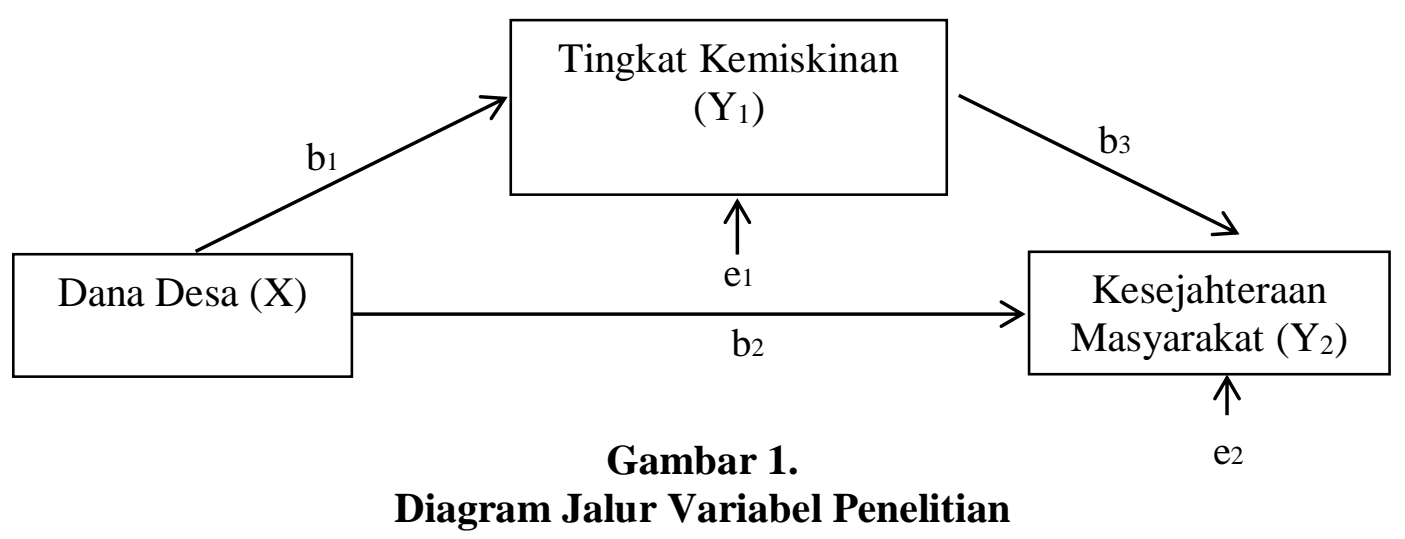

\section{HASIL DAN PEMBAHASAN}

Analisis statistik deskriptif memberikan gambaran atau deskripsi suatu data yang dilihat dari besarnya nilai minimum, maksimum, mean, dan simpangan baku (standard deviation) dengan $\mathrm{N}$ merupakan banyaknya responden penelitian. Hasil analisis statistik deskriptif dapat dilihat dalam Tabel 2.

Tabel 2.

\section{Hasil Statistik Deskriptif}

\begin{tabular}{lccc}
\hline & X & Y1 & Y2 \\
\hline Mean & 24.27745 & 4.939259 & 72.75556 \\
Maximum & 25.39064 & 7.440000 & 83.01000 \\
Minimum & 22.99779 & 2.060000 & 64.68000 \\
Std. Dev. & 0.637592 & 1.659627 & 5.572052 \\
Observations & 27 & 27 & 27 \\
\hline Sumber:Data & & &
\end{tabular}

Sumber:Data diolah, 2019

Statistik deskriptif pada Tabel 2 menunjukkan bahwa nilai minimum dan maksimum variabel dana desa (X) sebesar 22.99779 dan 25.39064. Rata-ratanya (mean) sebesar 24.27745dengan standar deviasi sebesar 0,637592, hal ini berarti bahwa terjadi perbedaan nilai dana desa yang diteliti terhadap nilai rata-ratanya 
sebesar 0,637592. Nilai minimum dan maksimum variabel tingkat kemiskinan $\left(\mathrm{Y}_{1}\right)$ sebesar 2,060000 dan 7.440000. Rata-ratanya (mean) sebesar 4.939259dengan standar deviasi sebesar 1.659627, hal ini berarti bahwa terjadi perbedaan nilai tingkat kemiskinan yang diteliti terhadap nilai rata-ratanya sebesar 1.659627. Nilai minimum dan maksimum kesejahteraan $\left(\mathrm{Y}_{2}\right)$ sebesar 83.01000dan 64.68000. Rata-ratanya (mean) sebesar 72.75556dengan standar deviasi sebesar 5.572052, hal ini berarti bahwa terjadi perbedaan nilai kemsikinan yang diteliti terhadap nilai rata-ratannya sebesar 5.572052 .

Berdasarkan hasil perhitungan koefisien determinasi total pada lampiran 6, yaitu $R_{m}^{2}=0,999$, maka diperoleh bahwa keragaman data yang dapat dijelaskan oleh model adalah sebesar 0,999 atau dengan kata lain informasi yang terkandung dalam data sebesar 99,9 persen dapat dijelaskan oleh model, sedangkan sisanya yaitu 00,1 persen dijelaskan oleh variabel lain yang tidak terdapat dalam model.

Pengujian ini dilakukan untuk melihat pengaruh dana desa terhadap tingkat kemiskinan secara langsung yang dilakukan dengan menggunakan program Eviews 9. maka hasil uji regresi disajikan dalam Tabel 3.

Tabel 3.

Hasil Uji Regresi Dana Desa Terhadap Tingkat Kemiskinan

\begin{tabular}{cccccc}
\hline \multirow{2}{*}{ Variable } & \multicolumn{2}{c}{ Coefficient } & \multirow{2}{*}{ Std. Error } & \multirow{2}{*}{ t-Statistic } & \multirow{2}{*}{ Prob. } \\
& Unstandardized & Standardized & & \multirow{2}{*}{. } \\
C & 17.425 & - & 1.804 & 9.657 & 0.000 \\
DD & -0.514 & -0.197 & 0.074 & -6.920 & 0.000 \\
\hline
\end{tabular}

Sumber: Data diolah, 2018

Berdasarkan perhitungan dengan menggunakan program Eviews9 diperoleh nilaiUnstandardized sebesar -0.514 dan nilai Standardized 
Coefficientsebesar -0.197 dan nilai prob. sebesar 0.000.Oleh karna nilai prob. dari variabel dana desa terhadap indeks pembangunan manusia sebesar $0.000<0.05$ ini berarti $\mathrm{H}_{0}$ ditolak $\mathrm{H}_{1}$ diterima, artinya dana desa $(\mathrm{X})$ berpengaruh negatif dan signifikan terhadap tingkat kemiskinan $\left(\mathrm{Y}_{1}\right)$.

Pengujian ini dilakukan untuk melihat pengaruh dana desa dan tingkat kemiskinan terhadap kesejahteraan masyarakat secara langsung yang dilakukan dengan menggunakan program Eviews 9. maka hasil uji regresi disajikan dalam Tabel 4.

Tabel 4.

Hasil Uji Regresi Dana Desa dan Tingkat Kemiskinan Terhadap Kesejahteraan Masyarakat

\begin{tabular}{cccccc}
\hline \multirow{2}{*}{ Variable } & \multicolumn{2}{c}{ Coefficient } & \multirow{2}{*}{ Std. Error } & t-Statistic & \multirow{2}{*}{ Prob. } \\
& Unstandardized & Standardized & & \\
\hline C & 63.458 & - & 5.746 & 11.042 & 0.000 \\
DD & 0.569 & 0.065 & 0.185 & 3.078 & 0.051 \\
KEMISKINAN & -0.917 & -0.273 & 0.289 & -3.169 & 0.041 \\
\hline
\end{tabular}

Sumber: Data diolah, 2018

Berdasarkan perhitungan dengan menggunakan program Eviews 9 diperoleh nilaiUnstandardized sebesar 0.569 dan nilai Standardized Coefficientsebesar 0.065 dan nilai prob. sebesar 0.051 . Oleh karna nilai prob. pengaruh dana desa terhadap tingkat kemiskinan sebesar $0.051<0.05$ ini berarti $\mathrm{H}_{0}$ ditolak $\mathrm{H}_{1}$ diterima, artinya dana desa $(\mathrm{X})$ berpengaruh positif dan signifikan terhadap kesejahteraan masyarakat $\left(\mathrm{Y}_{2}\right)$.

Berdasarkan perhitungan dengan menggunakan program Eviews 9 diperoleh nilaiUnstandardized sebesar -0.917 dan nilai Standardized Coefficientsebesar 0.273 dan nilai prob. sebesar 0.041. Oleh karna nilai prob. pengaruh indeks pembangunan manusia terhadap tingkat kemiskinan sebesar $0.041<0.05$ ini 
berarti $\mathrm{H}_{0}$ ditolak $\mathrm{H}_{1}$ diterima, artinya tingkat kemiskinan $\left(\mathrm{Y}_{1}\right)$ berpengaruh negatif dan signifikan terhadap kesejahteraab masyarakat $\left(\mathrm{Y}_{2}\right)$.

Berdasarkan hasil olahan data, pengaruh langsung suatu variabel terhadap variabel lainnya dalam penelitian ini disimpulkan pada Tabel 5. Berdasarkan Tabel 5, dapat dijelaskan bahwa variabel dana desa (X) berpengaruh negatif terhadap tingkat kemiskinan $\left(\mathrm{Y}_{1}\right)$ dengan nilai probabilitas sebesar 0.000 atau kurang dari 5 persen. Variabel dana desa $\left(\mathrm{X}_{1}\right)$ berpengaruh positif terhadap kesejahteraan masyarakat $\left(\mathrm{Y}_{2}\right)$ dengan nilai probabilitas sebesar 0.051 . Variabel tingkat kemiskinan $\left(\mathrm{Y}_{1}\right)$ berpengaruh negatif terhadap kesejahteraan masyarakat $\left(\mathrm{Y}_{2}\right)$ dengan nilai probabilitas sebesar 0.041 . Hubungan antar variabel penelitian secara lengkap juga disajikan pada diagram jalur Gambar 2. Berdasarkan gambar 2 apabila dicermati bahwa tidak ada koefisien jalur yang memiliki nilai lebih dari satu.

Tabel 5.

Pengaruh Langsung Antar Variabel Penelitian

\begin{tabular}{cccccl}
\hline Regresi & Coefficient & Std Error & T-statistic & Prob. & \multicolumn{1}{c}{ Keterangan } \\
\hline $\mathrm{XY} \longrightarrow$ & -0.917 & 0.074 & -6.920 & 0.000 & Negatif dan Signifikan \\
$\mathrm{X} \longrightarrow \mathrm{Y}_{2}$ & 0.065 & 0.185 & 3.078 & 0.051 & Positif dan Signifikan \\
$\mathrm{Y}_{1} \longrightarrow$ & -0.273 & 0.289 & -3.169 & 0.041 & Negatif dan Signifikan \\
\hline \multicolumn{2}{l}{ Sumber: } & Data diolah, 2018 & &
\end{tabular}

Berdasarkan Gambar 1 variabel dana desa (X) memiki keofisien jalur sebesar $-0,917$ terhadap variabel tingkat kemiskinan $\left(\mathrm{Y}_{1}\right)$. Variabel tingkat kemiskinan $\left(\mathrm{Y}_{1}\right)$ memiliki pengaruh negatif terhadap kesejahteraan masyarakat $\left(\mathrm{Y}_{2}\right)$ dengan koefisien jalur sebesar -0.273 sedangkan dana desa $(\mathrm{X})$ memiliki pengaruh positif terhadapkesejahteraan masyarakat $\left(\mathrm{Y}_{2}\right)$ dengan koefisien jalur sebesar 0.065 . 


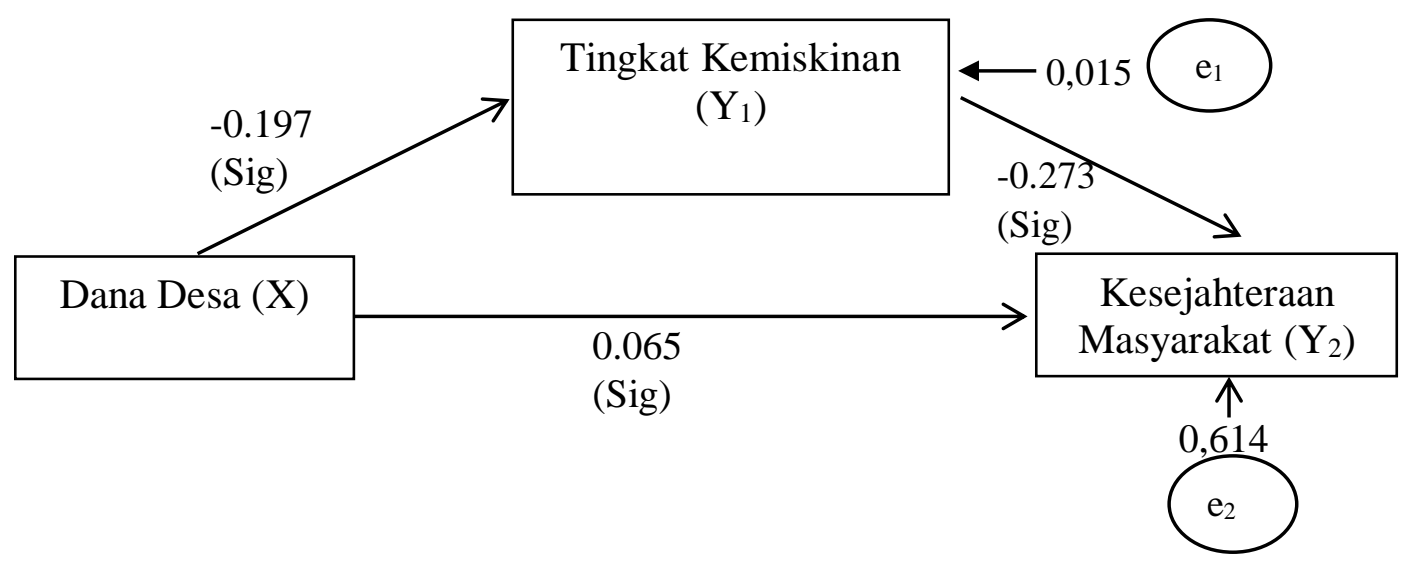

Gambar 2.

Koefisein Jalur Hubungan Antarvariabel Penelitian

Pengaruh tidak langsung suatu variabel terhadap variabel lainnya dalam penelitian ini disajikan pada Tabel6.

Tabel 6.

Pengaruh Tidak Langsung (Indirect Effect) Variabel Penelitian

\begin{tabular}{cccccc}
\hline $\begin{array}{c}\text { Hubungan } \\
\text { Antarvariabel }\end{array}$ & $\begin{array}{c}\text { Variabel } \\
\text { Mediasi }\end{array}$ & axb & Sab & $\mathrm{Z}$ & Keterangan \\
\hline $\mathrm{X}_{1} \stackrel{\mathrm{Y}}{\longrightarrow} \longrightarrow$ & $\mathrm{Y}_{1}$ & 0.250 & 0,163 & 2.891 & Signifikan \\
\hline Sumber: & Data diolah, 2018 & & & &
\end{tabular}

Berdasarkan Tabel 6, menunjukkan bahwa pengaruh tidak langsung dana desa $(\mathrm{X})$ terhadap tingkat kesejahteraan masyarakat $\left(\mathrm{Y}_{2}\right)$ melalui tingkat kemiskinan $\left(\mathrm{Y}_{1}\right)$ memiliki nilai $\mathrm{Z}$ sebesar 2,891 lebih besar dari 1,96. Hal tersebut membuktikan bahwa secara tidak langsung dana desa (X) melalui tingkat kemiskinan $\left(\mathrm{Y}_{1}\right)$ berpengaruh terhadap kesejahteraan masyarakat.

Tabel 7.

Koefisien Hubungan Langsung, Tidak Langsung, dan Total Antarvariabel

\begin{tabular}{lccc}
\hline \multirow{2}{*}{$\begin{array}{c}\text { Hubungan } \\
\text { Variabel }\end{array}$} & Langsung & $\begin{array}{c}\text { Tidak Langsung } \\
\text { melalui Y1 }\end{array}$ & Pengaruh Total \\
\cline { 2 - 3 } & -0.917 & - & 0.215 \\
$\mathrm{X} \longrightarrow \mathrm{Y}_{1}$ & 0.065 & 0.250 & 0.016 \\
$\mathrm{X} \longrightarrow \mathrm{Y}_{2}$ & -0.273 & - & 0.135 \\
$\mathrm{Y}_{1} \mathrm{Y}_{2} \rightarrow$ & & &
\end{tabular}


Berdasarkan uraian di atas, Tabel 7 dapat diketahui nilai pengaruh langsung dana desa terhadap tingkat kemiskinan-0,917. Pengaruh langsung dana desa terhadapkesejahteraan masyarakat sebesar 0,065 . Pengaruh langsungtingkat kemiskinan terhadapkesejahteraan masyarakat sebesar -0,273. Pengaruh tidak langsung dana desa terhadap kemiskinan melalui indeks pembangunan manusia adalah sebesar 0.250 .

Hasil analisis menujukkan bahwadana desa berpengaruh negatif dan signifikan terhadap tingkat kemiskinan. Pemberian dana desa merupakan wujud dari pemenuhan hak desa untuk menyelenggarakan otonominya agar tumbuh dan berkembang. Peran pemerintah desa dalam memberikan pelayanan, kesejahteraan masyarakat dan mempercepat pembangunan serta pertumbuhan wilayah-wilayah strategis harus ditingkatkan, sehingga dapat mengembangkan wilayah-wilayah yang masih tertinggal dalam suatu sistem wilayah pengembangan. Peningkatan kualitas dan perluasan ruang lingkup dari pelayanan pokok tersebut membutuhkan investasi sumber daya manusia sumber daya manusia yang berkualitas dan pada akhirnya akan meningkatkan produktivitas golongan miskin (Lestari, 2017).

Hasil penelitian ini di dukung dengan beberapa penelitian yang dilakukan oleh Gunatilaka (2001), Ahmad dan Tanzi (2002), Nanga (2006), Hong (2010) yang menyatakan desentralisasi mempunyai hubungan yang erat dalam pengentasan kemiskinan di suatu daerah. Secara spesifik penelitian ini juga didukung hasil kajian Prasetyanto (2012) yang menyatakan ADD mampu meningkatkan kinerja fiskal dan perekonomian daerah, mampu mengurangi jumlah penduduk miskin. 
Berdasarkan hasil pengujian hipotesis menujukkan dana desa berpengaruh positif dan signifikan terhadap kesejahteraan masyarakat. Hasil penelitian ini menunjukkan dana desa memiliki hubungan yang positif dan signifikan terhadap kesejahteraan masyarakat. Hal ini berarti bahwa dana desa akan mempengaruhi kesejahteraan masyarakat.Berkenaan dengan dikucurkannya dana desa dan alokasi dana desa diharapkan proses pembangunan daerah secara keseluruhan akan dapat ditingkatkan dan secara bersama ketimpangan pembangunan antar wilayah akan pula dapat dikurangi. Alokasi dana yang merata dan tepat sasaran serta pengelolaan sumber-sumber pendapatan secara optimal, efisien dan efektifitas dalam penggunaan anggaran belanja merupakan hal pokok yang harus selalu diperioritaskan. Pemerintah memiliki posisi yang sangat penting dalam menciptakan keadilan distribusi, karena menciptakan kesejahteraan di masyarakat merupakan kewajiban seluruh agen ekonomi.Disamping itu, pemerintah juga berperan sebagai penjamin terciptanya distribusi yang adil serta menjadi fasilitator pembangunan manusia dan menciptakan kesejahteraan masyarakat (Pitri, 2018).

Dana desa merupakan dana yang bersumber dari APBN yang diperuntukkan untuk desa, dananya ditransfer melalui anggaran belanja daerah kabupaten. Dana Desa ini digunakan untuk membiayai penyelenggaraan pemerintahan desa, pelaksanaan pembangunan desa, pembinaan kemasyarakatan desa, dan pemberdayaan masyarakat desa. Tujuan dana desa adalah untuk mengentaskan kemiskinan. Penggunaan dana desa digunakan untuk pemerintahan desa sebesar 30 persen dan 70 persen untuk pemberdayaan masyarakat dan pembangunan. Tujuan penelitian ini adalah untuk menganalisis pengaruh dana 
desa pada pembangunan desa, pembinaan kemasyarakatan desa dan pemberdayaan masyarakat desa terhadap jumlah penduduk miskin.

Pemberian dana desa merupakan wujud dari pemenuhan hak desa untuk menyelenggarakan otonominya agar tumbuh dan berkembang. Perbaikan akses terhadap konsumsi pelayanan sosial (pendidikan, kesehatan dan gizi) merupakan alat kebijakan penting dalam strategi pemerintah secara keseluruhan untuk mengurangi angka kemiskinan dan memperbaiki tingkat kesejahteraan dalam suatu wilayah.

Hasil penelitian ini didukung dengan penelitian yang dilakukan oleh Rusydi (2012) yang menyatakan kegiatan pengalokasian ADD cukup efektif untuk meningkatkan kesejahteraan masyarakat. Oleh kerana itu kegiatan pengawasan perlu dilakukan untuk memastikan agar tidak ada penyelewengan anggaran dan benarbenar diperuntukkan sebagaimana mestinya. Pengawasan adalah kegiatan mengumpulkan informasi tentang perkembangan atau pelaksanaan sebuah kegiatan. Pengawasan biasanya dilakukan secara berkala selama proses berlangsungnya kegiatan terkait. Sementara evaluasi adalah kegiatan menilai secara keseluruhan apakah sebuah kegiatan telah dilaksanakan sesuai dengan rencana atau kegiatan yang telah disusun sebelumnya. Evaluasi biasanya dilakukan pada akhir suatu kegiatan.

Hasil pengujian menujukkan tingkat kemiskinan berpengaruh negatif dan signifikan terhadap kesejahteraan. Indeks Pembangunan Manusia memiliki implikasi penting terhadap penurunan tingkat kemiskinan. Indeks Pembangunan Manusia (IPM) mengukur capaian pembangunan manusia berbasis sejumlah 
komponen dasar kualitas hidup. Sebagai ukuran kualitas hidup, Indeks Pembangunan Manusia dibangun melalui pendekatan tiga dimensi dasar. Dimensi tersebut mencakup umur panjang dan sehat, pengetahuan, dan kehidupan yang layak. Ketiga dimensi tersebut memiliki pengertian sangat luas karena terkait banyak faktor. Untuk mengukur dimensi kesehatan, digunakan angka harapan hidup waktu lahir. Selanjutnya untuk mengukur dimensi pengetahuan digunakan gabungan indikator angka melek huruf dan rata-rata lama sekolah. Adapun untuk mengukur dimensi hidup layak digunakan indikator kemampuan daya beli masyarakat terhadap sejumlah kebutuhan pokok yang dilihat dari rata-rata besarnya pengeluaran per kapita sebagai pendekatan pendapatan yang mewakili capaian pembangunan untuk hidup layak. Menurut Irma (2015) dana desa untuk pembangunan desa berpengaruh signifikan dengan arah negatif terhadap penduduk miskin. Arah positifnya menunjukkan bertambahnya danadesa maka berkurangnya jumlah penduduk miskin, sehingga penggunaan dana desa tidak tepat sasaran.

Indeks pembangunan manusia memuat tiga dimensi penting dalam pembangunan yaitu terkait dengan aspek pemenuhan kebutuhan akan hidup panjang umur (Longevity) dan hidup sehat (healthy life), untuk mendapatkan pengetahuan (the knowledge) dan mempunyai akses kepada sumberdaya yang bisa memenuhi standar hidup. Artinya, tiga dimensi penting dalam pembangunan manusia tersebut sangat berpengaruh terhadap kemiskinan (Yani Mulyaningsih, 2008).Pembangunan manusia berkaitan dengan pengurangan kemiskinan. Investasi di bidang pendidikan dan kesehatan akan lebih berarti 
bagi penduduk miskin dibandingkan penduduk tidak miskin, karena bagi penduduk miskin aset utama adalah tenaga kasar mereka. Adanya fasilitas pendidikan dan kesehatan murah akan sangat membantu untuk meningkatkan produktivitas, dan pada gilirannya meningkatkan pendapatan dan menurunkan angka kemiskinan(Saputra, 2011).

Hasil penelitian ini didukung dengan penelitian yang dilakukan Mirza (2012) dan Suradi (2007) yang menyatakan menyatakan bahwa kemiskinan berkaitan erat dan ikut menentukan proses pembangunan yang mengedepankan partisipasi masyarakat. Paradigma pembangunan yang kini bergeser dari dominasi peran negara kepada peran masyarakat tidak akan dapat diwujudkan apabila jumlah penduduk miskin masih cukup signifikan. Hal demikian dikarenakan pada umumnya penduduk miskin lebih banyak menghabiskan tenaga dan waktu yang ada untuk pemenuhan kebutuhan dasar. Mereka tidak tertarik untuk melibatkan diri pada aktivitas-aktivitas yang tidak secara langsung berkaitan dengan 13 pemenuhan kebutuhan dasar. Hasil penelitian-penelitian tersebut memperjelas bahwa semakin tinggi populasi penduduk miskin akan menekan tingkat pembangunan manusia, sebab penduduk miskin memiliki daya beli yang rendah.

Hasil pengujian menujukkan tingkat kemiskinan memediasi dana desa terhadap kesejahteraan masyarakat. Artinya semakin tinggi dana desa maka kesejahteraan meningkat semakin meningkat sehingga kemiskinan menurun. Berdasarkan hasil analisis data dan pembahasan yang telah dilakukan dapat diketahui bahwa sesuai dengan tujuan penelitian yaitu untuk menganalisis pengaruh Dana Desa terhadap kemiskinan desa di kabupaten/kota Provinsi Bali 
tahun 2015- 2017. Penelitian ini didukung oleh penelitian yang dilakukan oleh Meriyanti (2015), mengenai pengaruh program IPM terhadap pengentasan kemiskinan di Kecamatan Buleleng, Kabupaten Buleleng tahun 2011- 2014, dapat diketahui bahwa program IPM mempengaruhi pengentasan kemiskinan di Kecamatan Buleleng, Kabupaten Buleleng. Kemiskinan dapat diturunkan melalui dana desa dan indeks pembangunan manusia dengan cara pemberian bantuan tepat sasaran seperti pembangunan sarana pendidikan dan kesehatan yang akan mengakibatkan peningkatan kualitas sumber daya manusia yang akan berpengaruh terhadap kemiskinan masyarakat.

\section{SIMPULAN}

Dana desa berpengaruh negatif dan signifikan terhadap tingkat kemiskinan. Artinya bahwa semakin tinggi dana desa maka semakin turun tingkat kemiskinan.Dana desa berpengaruh positif dan signifikan terhadap kesejahteraan masyarakat. Artinya bahwa semakin tinggi dana desa maka akan semakin tinggi kesejahteraan masyarakat di daerah tersebut. Tingkat kemiskinan berpengaruh negatif dan signifikan terhadap kesejahteraan masyarakat artinya semakin tinggi tingkat kemiskinan maka semakin menurun kesejahteraan masyarakat.Tingkat kemiskinan merupakan variabel intervening pengaruh dana desa terhadap kesejahteraan masyarakat di Kabupaten/Kota Provinsi Bali.

Pemerintah diharapkan terus melanjutkan program dana desa untuk meningkatkan indeks pembangunan manusia serta mengentaskan kemiskinan dan mengupayakan agar masyarakat tidak kembali mengalami kemiskinan.Pemerintah 
sebaiknya meningkatkan kualitas pendidikan, kesehatan melalui perbaikan sarana pendidikan dan kesehatan sehingga angka indeks pembangunan manusia dapat semakin meningkat dan mendorong pencapaian tujuan nasional yang mensejahterakan masyarakat.

\section{REFERENSI}

Artana Yasa, Komang Oka; Arka, Sudarsana. Pengaruh Pertumbuhan Ekonomi Dan Disparitas Pendapatan Antar daerah Terhadap Kesejahteraan Masyarakat Provinsi Bali.Jurnal Ekonomi Kuantitatif Terapan, [S.1.], nov. 2015. ISSN 2303-0186.

Bakhtyar, Zaharim, Sopian and Moghimi. 2013. Housing For Poor People: A Review On Low Cost Housing Process In Malaysia. Wseas Transactions On Environment and Development, University Kebangsaan Malaysia, Vol. 9, Issue 2, ISSN:2224-3496.

BPS Provinsi Bali. 2017. Bali Dalam Angka 2017. Denpasar: BPS.

Ceu Thang and Baharuddin. 2011. Poverty Reduction: A Continuos Social Responsibility In Malaysia. International Journal Of Rural Studies, Vol. 18, No. 2, ISSN:1023-2001.

Dariwardani, Ni Made Inna. Analisis Dinamika Kemiskinan (Proverty Dynamics) Di Bali Berdasarkan Data Susenas Panel 2008 - 2010. Jurnal Ekonomi Kuantitatif Terapan, [S.1.], may 2014. ISSN 2303 - 0186.

Dayuh Rimbawan, Nyoman. 2012. Pertumbuhan Ekonomi Dan Kegiatan Ekonomi Angkatan Kerja Di Provinsi Bali. Piramida, 6(2): 1918 - 1923.

Edogbanya, Adejoh. 2013. Revenue Generation: Impact on Government Developmental Effort (A Study of Selected Local Council in Kogi East Senatorial District). Global Journal of Management and Business Research.

Gjorgievski, Mijalce., Gramatnikovski, Sasko.,and Nakovski, Dejan. 2013. Geographic Positioning as a Determination of Tourism Development of Gevgelija Region. UTMS Journal of Economics, Vol.4, No.1, Hal: 61-69.

Hukom, Alexandra. 2014. Hubungan Ketenagakerjaan Dan Perubahan Struktur Ekonomi terhadap Kesejahteraan Masyarakat. Jurnal JEKTJurusan Ilmu 
Ekonomi dan Studi Pembangunan Fakultas Ekonomi Universitas Palangka Raya. 7 (2). 120-129.

Kaur, M., \& Singh, L. 2016. Knowledge in the economic growth of developing economies. African Journal of Science, Technology, Innovation and Development, 8(2), 205-212.

Khuzaironi. 2015. Pengaruh Kebijaksanaan Apbd Dan Kemiskinan Terhadap Kesejahteraan Masyarakat Di Provinsi Jawa Tengah. Skripsi Sarjana Fakultas Ekonomika dan Bisnis Universitas Diponogoro. Semarang.

Lestari, Riana Puji. 2017. Analisis Pengaruh Indeks Pembangunan Manusia, Penggangguran dan Produk Domistik Bruto Terhadap Tingkat Kemiskinan Di Provinsi Lampung Dalam Perspektif Ekonomi Islam Tahun 2011-2015 . Skripsi Fakultas Ekonomi dan Bisnis Islam Universitas Islam Negeri Raden Intan. Lampung.

Margareni, Ni Putu Ayu Purnama., I Ketut Djayastra dan I.G.W Murjana Yasa. 2016. Faktor-faktor Yang Mempengaruhi Kemiskinan Di Provinsi Bali. Piramida Vol. XII No. 1: 101-110.

Marhaeni, AAIN. 2014. EvaluasiProgram-Program Pengentasan Kemiskinan di Provinsi Bali. Piramida Vol. X No. $1: 8-18$.

Mendes, Philip. 2009. Retrenching Or Renovating The Australian Welfere State: The Paradox Of The Toward Government's Neo-Liberalism. International Journal Of Social Welfare, Vol. 18, Issue 1, Pages:102-110, ISSN:13696866.

Nurcholis, H. 2011. Pertumbuhan dan Penyelenggaraan Pemerintah Desa. Jakarta: Erlangga.

Nurudeen, A., and Usman, A. 2010. Government Expenditure and Economic Growth in Nigeria, 1970-2008: A Disaggregate Analysis. Business and Economic Journal. 4. Hal: 1-11.

Odhiambo, N. M. 2009. Savings and economic growth in South Africa: A multivariate causality test. Journal of Policy Modeling, 31(5), 708-718.

Pitri, Savarita. 2018. Analisis Manajemen Dana Desa Terhadap Pembangunan Desa Dalam Perspektif Ekonomi Islam. Skripsi Fakultas Ekonomi dan Bisnis Islam Universitas Islam Negeri Raden Intan. Lampung.

Pramitha, Murjana Yasa dan Marhaeni. 2015. Peranan Dana Bantuan Sosial Terhadap Kualitas Rumah Masyarakat Miskin Melalui Program Bedah Rumah di Kabupaten Buleleng. E-jurnal Ekonomi dan Bisnis, Universitas Udayana, 4.02, hal. 106-124, ISSN:2337-3067. 
Putra dan Sri Budhi. 2015. Efektivitas Dan Dampak Program Nasional Pemberdayaan Masyarakat Mandiri Perdesaan (Pnpm-Mpd) Terhadap Peningkatan Kesejahteraan Dan Kesempatan Kerja Rumah Tangga Sasaran Di Kecamatan Abiansemal Kabupaten Badung. E-Jurnal Ekonomi dan Bisnis Universitas Udayana, Hal: 183-196.

Rudy Syaf, Syurya Hidayat dan Erni Achmad. 2013. Faktor-faktor Yang Mempengaruhi Pendapatan Rumah Tangga Miskin Di Sekitar Taman Nasional Bukit Dua Belas (Studi Kasus Desa-Desa PenyangganTnbd Di Kecamatan Maro Sebo Ulu, Kabupaten Batang Hari). Jurnal Perspektif Pembiayaan dan Pembangunan Daerah, Vol.1, No.2.

Seran, Sirilius. 2017. Hubungan Antara Pendidikan, Pengangguan dan Pertumbuhan Ekonomi dengan Kemiskinan. Jurnal JEKT 10 (1) : 59-71

Sri budhi, Made Kembar. 2013. Analisis Faktor-faktor Yang Berpengaruh Terhadap Pengentasan Kemiskinan Di Bali: Analisi FEM Data Panel. Jurnal Ekonomi Kuantitatif Terapan,[S.1.], feb. 2013. ISSN 2303-0186.

Suhartini, Atik Mar'atis; Yuta, Ropika. Keterkaitan Lembaga Keuangan Mikro (LKM), Usaha Mikro dan Kecil (UMK) serta Kemiskinan di Indonesia Tahun 2012. Jurnal Ekonomi Kuantitatif Terapan, [S.1.], nov. 2015. ISSN 2303-0186.

Sukmaraga, Prima. 2011. Analisis Pengaruh Indeks Pembangunan Manusia, PDRB Per Kapita, dan Jumlah Pengangguran Terhadap Jumlah Penduduk Miskin Di Provinsi Jawa Tengah. Semarang; Skripsi, Fakultas Ekonomi Univesitas Diponegoro.

Sutikno, Eddy Setiadi, Agnes Tuti Rumiati dan Lantip Trisunarno. 2010. Pemilihan Program Pengentasan Kemiskinan Melalui Pengembangan Model Pemberdayaan Masyarakat Dengan Pendekatan Sistem. Jurnal Ekonomi Pembangunan, Volume 11, Nomor 1, hal.135 - 147.

Tajeddini, Kayhan, Alf H. Walle \&Mela Denisa. 2017. Enterprising Women, Tourism, and Development: The Case of Bali.International Journal of Hospitality \& Tourism Administration.ISSN: 1525-6480.

Viken, Arvid 2011. Tourism, Research, And Governance On Svalbard: A Symbiotic Relationship. The Polar Record, Vol.47, No.4, Hal: 335-347.

Vojnovic, Knezevic dan Rade Knezevic. 2013. Economic And Tourism Indicators As A Means Of Monitoring Sustainable Tourism: The Case Of Inland Istria. UTMS Journal of Economics, Vol. 4, No.2, Hal: 213-230.

Wirawan. 2015. Efektivitas Program Bantuan Usaha Ekonomi Produktif (Uep) Dalam Upaya Peningkatan Kesempatan Kerja Dan Pendapatan Rumah 
Made Krisna Kalpika Sunu dan Made Suyana Utama. Pengaruh Dana Desa Terhadap.

Tangga Miskin Di Kecamatan Kerambitan. Jurnal Universitas Pendidikan Ganesha Singaraja, Vol:5 No: 1.

Yusuf dan Sumner. 2015. Growth, Poverty, and Inequality Under Jokowi. Bulletin Of Indonesian Economic Studies, Vol.51, No.3, ISSN:0007-4918. 